\section{The Influx of Red-FOOTED FALCONS Falco vespertinus IN SLOVENIA IN SPRING 2015}

\section{Invazija rdečenogih postovk Falco vespertinus v Sloveniji spomladi 2015}

\section{JURIJ HANŽEL ${ }^{1 *}$}

1 Židovska ul. 1, SI-1000 Ljubljana, Slovenia, e-mail: jurij. hanzel@gmail.com

The Red-footed Falcon Falco vespertinus is widely distributed from eastern Europe to north central Asia, with its main European breeding populations (in descending order of size) in Russia, Ukraine, Romania and Hungary (Ferguson-Lees \& Christie 200I, BirdLife InTERnATIONAL 2015). The species is a long distance migrant wintering in southern Africa from Angola and Zambia to northern South Africa (Ferguson-Lees \& Christie 200I). It is known to migrate in a loop: flying along a broad front through the eastern Mediterranean in autumn and following a more westerly route in spring (GLUTZ von BlotZheim et al. 1989). Influxes of the species into western and central Europe are known to occur particularly in spring, when migration coincides with anticyclonic systems in eastern Europe (FERGUSONLEES \& CHRISTIE 200I). Meteorological conditions further south along the species' migration route could conceivably also play a role in these influxes, even though this hypothesis remains unproven. Recent large spring influxes took place in 2008 (MAYER \& KRATZER 2009, VOLET \& Gerber 2009) and 1992 (HAgEMEIJER i 994, Nightingale \& Allsopp i 994).

In Slovenia, the species occurs regularly on migration, much more commonly in spring than in autumn (TOME et al. 2005, BORDJAN \& BOžIČ 2009, BORDJAN 2OI 2). The spring migration of the species lasts from late April to early June with a peak in mid-May (TOME et al. 2005, BORDJAN 2012). Based on limited data, the number of migrating Red-footed Falcons through Slovenia in spring was estimated at 500-2000 individuals (DENAC et al. 201 I). The highest numbers were observed at Lake Cerknica and Ljubljansko barje with highest daily counts of 1000 (BORDJAN 2010) and 42 individuals (TOME et al. 2005), respectively. The seasonal totals are estimated at 300-1500 individuals

Luka Božič served as editor for this paper. / Uredniško delo za ta članek je opravil Luka Božič. for the former (Bordjan 20Io, Denac et al. 20I I) and 100-200 for the latter areas (DENAC et al. 201 I). An influx has never been thoroughly documented in Slovenia, although some of the highest daily totals were recorded in 1992 (KMECL \& RIŽNER I993) and 2008 (BORDJAN 2010), when influxes were documented elsewhere in central and western Europe. This paper describes the influx of Red-footed Falcons recorded in Slovenia in spring 2015.

Data were collected from the online database Atlas ptic - NOAGS [http:// http://atlas.ptice.si/ atlas], through requests for records on local birding newsgroups and directly from observers. To avoid double registrations, only the highest daily count was used when several counts were made on the same day at the same site. The maximum was calculated assuming complete independence of sightings between days by simple addition. The minimum was calculated by merely adding the difference between two consecutive daily counts at a given site to the grand total, e.g. if 100 birds were seen on the first day and 123 on the second, only the surplus birds counted on the second day were added, thereby yielding a total of 123 birds for the two days. Data from satellite-tracked birds was obtained at [www.satellitetracking.eu].

The first Red-footed Falcon in spring 2015 was reported on 15 Apr. Smaller flocks of up to 20 birds were reported until 13 May, when the actual influx began (Figure 1). The vast majority of birds was reported between 13 and 18 May, with the highest daily total of 1,146 birds on 16 May. The daily counts subsequently fluctuated between 1 and 38 until 28 May, when higher numbers with 82 observed birds were noted again. Another 142 birds were observed on 2 Jun 2015, as well as groups of up to 6 individuals irregularly until 29 Jun 2015 (not shown in Figure 1).

During the influx (13 May-3 Jun 2015), 39104370 Red-footed Falcons were observed in Slovenia. Birds were reported from lowlands throughout Slovenia (Figure 2). None were reported from alpine or extensively forested regions. Sites with the highest numbers of roosting and feeding birds were Ljubljansko barje, particularly between Ig and Škofljica in its southeastern corner (567-883 individuals), Lake Cerknica (710 individuals), Lake Zbilje (250 individuals) and the Medvedce reservoir (110-189 individuals). Large flocks that migrated without stopping were observed at Št. Jurij near Grosuplje (500 individuals), Velika Pirešica near Žalec (406 individuals) and Lake Ormož (206 individuals).

Even though some birds marked with colour rings were observed, none were read. A satellite-tracked adult male, named Ubul, passed through Slovenia on 25 and 


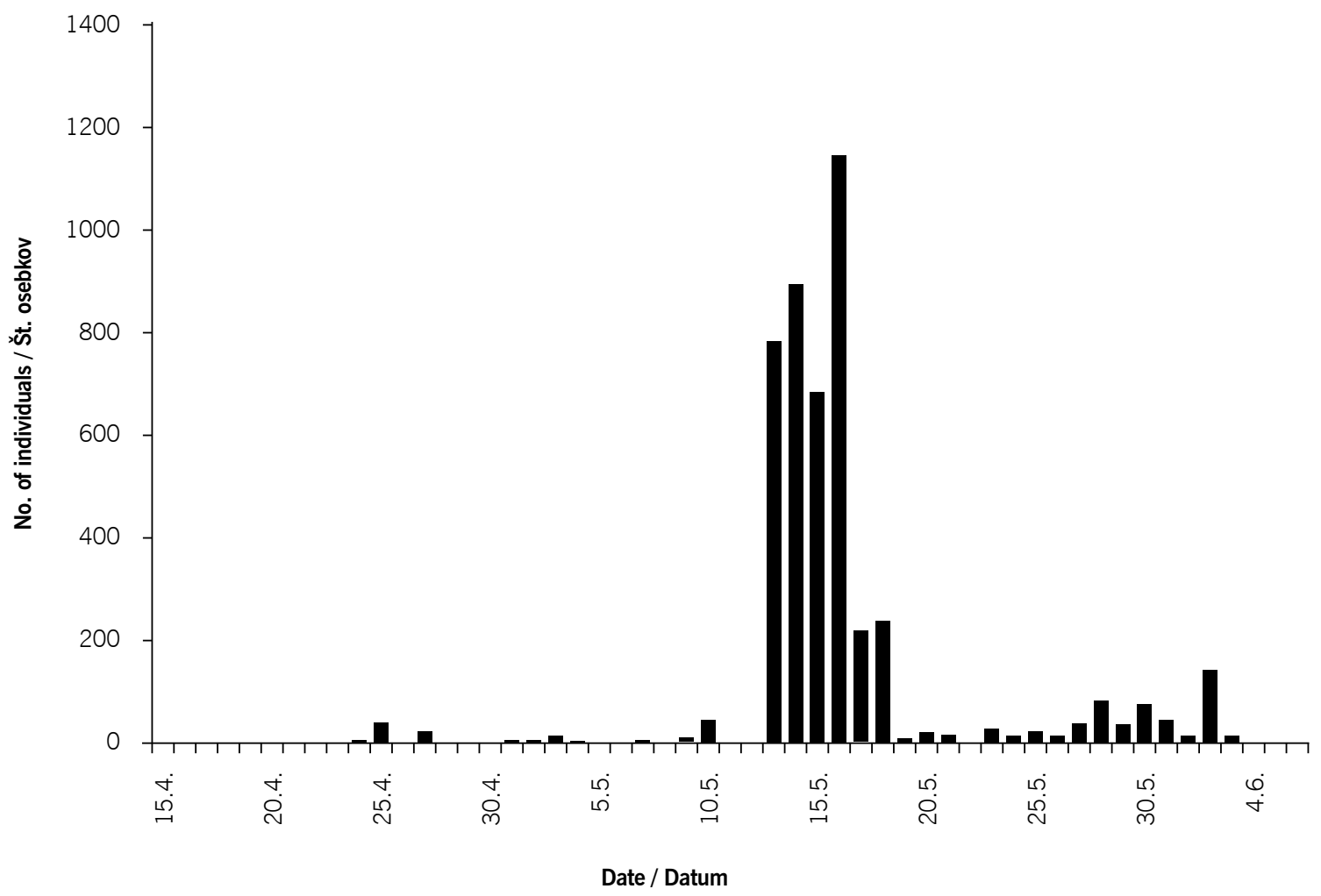

Figure 1: Phenology of Red-footed Falcons Falco vespertinus during the influx in Slovenia in spring 2015. The graph shows the total number of individuals observed on a given day. The highest daily total was used for sites visited by several observers on a given day.

Slika 1: Fenologija rdečenogih postovk Falco vespertinus med invazijo v Sloveniji spomladi leta 2015. Graf prikazuje vsoto vseh osebkov, opazovanih na posamezen dan. Za lokacije, kjer je isti dan štelo več opazovalcev, je bilo uporabljeno največje število za tisti dan.

26 Jun, roosting at Ljubljansko barje. It then continued migration to southern Ukraine, but did not breed there (ORBÁN 2OI5).

The number of Red-footed Falcons observed in Slovenia in spring 2015 exceeded all hitherto recorded spring migration totals, with a previous tentative upper estimate of 2000 migrating individuals (DENAC et al. 20I I). The daily and seasonal highest totals were both exceeded at Ljubljansko barje (TOME et al. 2005, DenaC et al. 201 I), but not at Lake Cerknica. The lake was thoroughly checked for Red-footed Falcons on a single day during the influx, which was probably the cause for lower counts than expected based on the situation elsewhere in the country. The number of individuals that could have been counted twice at different sites within Slovenia was probably offset by the number of overlooked birds, particularly at Lake Cerknica.

The European breeding population is estimated at 60,600-127,000 mature individuals (BIRDLIFE
INTERNATIONAL 2015), which means that up to 3.17.2\% migrated through Slovenia in spring 2015. The species is listed as near-threatened both in Europe and globally and as vulnerable within the EU (BIRDLIFE InTERnATIONAL 2015). Two Important Bird Areas (IBAs) were designated for the species in Slovenia: Ljubljansko barje and Lake Cerknica (Denac et al. 20I I). The influx of 2015 confirmed their status as key stopover and roosting sites.

Elsewhere in Europe during spring 2015, Redfooted Falcons were recorded further west and in higher numbers than usually. Birds were seen in the Canary Islands, including the westernmost El Hierro (GIl Velasco 20I5), on Madeira (Wind Birds 2015) and mainland Portugal (Geraldes 2015), where they are otherwise uncommon or rare (Matias et al. 2007, Romano et al. 2010, GIL Velasco 2015). In Spain, the species was particularly numerous in Catalonia where higher numbers of birds started to appear from 15 


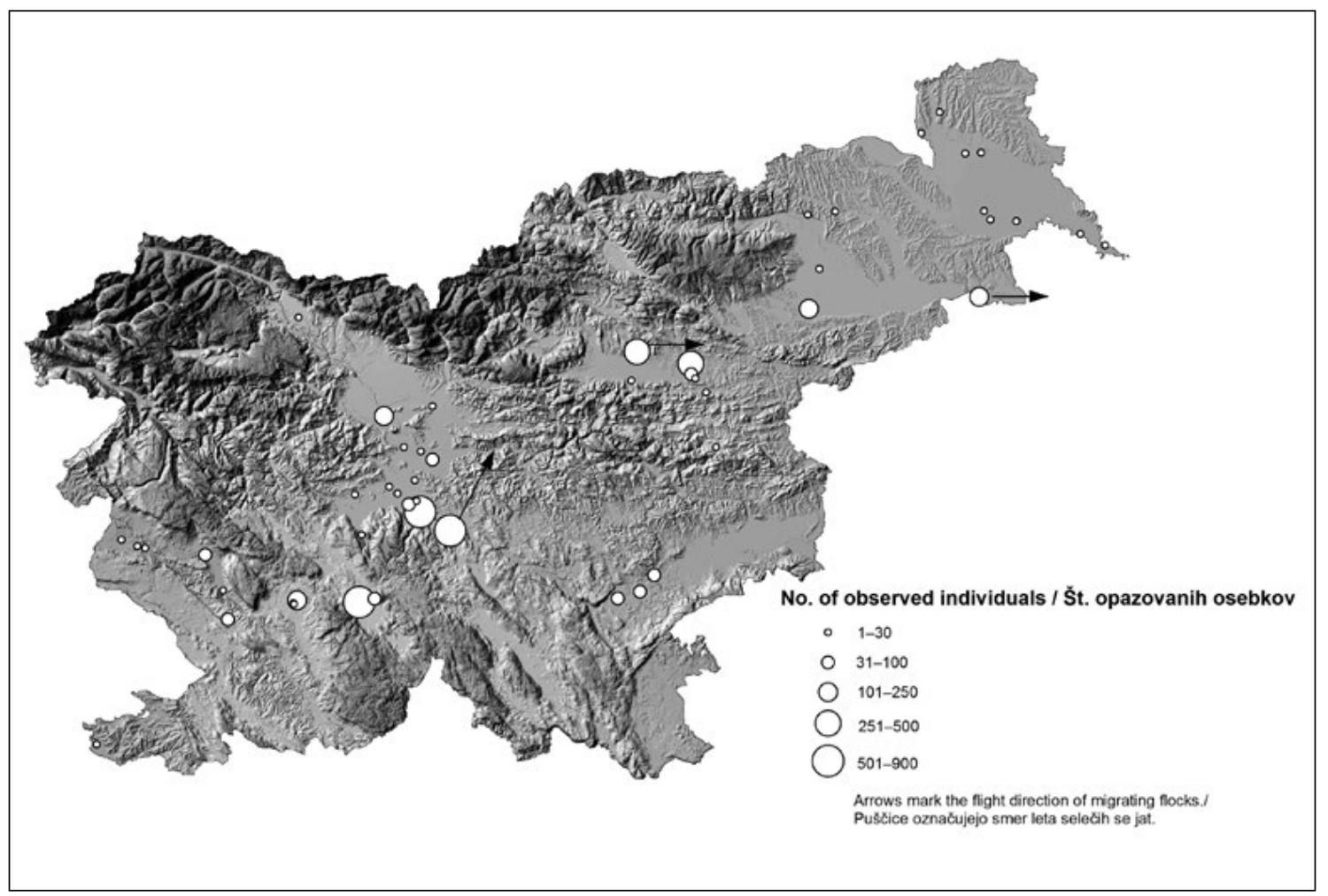

Figure 2: Spatial distribution of Red-footed Falcons Falco vespertinus during the influx in Slovenia in spring 2015. The map shows the sum of all observed individuals per site, with the provision of using the highest daily count for days when several observers visited the same site on a given day.

Slika 2: Prostorska razporeditev rdečenogih postovk Falco vespertinus med invazijo v Sloveniji spomladi 2015. Zemljevid prikazuje vsoto vseh opazovanih osebkov za posamezno lokacijo, pri čemer je za lokacije, kjer je isti dan štelo več opazovalcev, uporabljeno največje število za tisti dan.

May onwards, with a total of 527 birds and the largest flock exceeding 100 individuals (Illa 2015). The influx continued into southern France and north of the Alps across Switzerland to southern Germany, with above average numbers recorded in northeastern Italy and southern Austria as well (SCHMid 2015). A total of 15,564 birds were reported in these countries and Catalonia between 9 Apr and 22 May 2015. Nevertheless, no provisions could be made for double registrations, so the actual number of birds must have been lower.

Such influxes have usually been attributed to a combination of local factors (abundance of cockchafers Melolontha sp.) and broader meteorological developments (strong southeasterly and easterly winds diverting birds further to the west and northwest) (Hagemeijer 1994, Nightingale \& Allsopp 1994, MaUmary et al. 2007). A link between abundant food supply and the occurrence of Red-footed Falcons was noted in Slovenia in 2008 (BORDJAN 2012), but not convincingly so in 2015. Moreover, abundant supply of prey is thought to cause the birds to interrupt their migration and stay at a given site for a longer period, rather than precipitate the influx itself (MAUMARY et al. 2007). The 1992 influx to northwestern Europe was importantly influenced by meteorological conditions: immediately before the influx the jet stream shifted northwards, thus causing a northward movement of warm subtropical air masses. The steady northward movement of air, along with a westward movement from eastern Europe, which continued well into June, were both thought to have assisted the influx (Hagemeijer i 994, Nightingale \& Allsopp i 994). No clear meteorological pattern that could have facilitated an influx was identified in 2015. Strong southeasterly winds were reported from Sahara between 12 and 17 May 2015, which led to the occurrence of unusually numerous Honey Buzzards Pernis apivorus in Western Sahara. Only two Red- 
footed Falcons were seen, but these were also the first records for the territory (CHEVALIER et al. 2015). During years with influxes of Red-footed Falcons, other migratory species are often seen in above average numbers (HAGEMEIJER I994, Nightingale \& Alsopp 1994). In 2015, this was the case with Icterine Warblers Hippolais icterina, particularly in Catalonia (Oliver 2015), but not in Slovenia (AtLas PTIC 2015, D. FeKonja pers. comm.). The species shares a portion of its wintering range with the Red-footed Falcon (GLUTZ VON BLOTZHEIM \& BAUER I99I), which lends some credibility to the hitherto unproven speculation that meteorological perturbations further south along the migration route may be the cause of such influxes.

Acknowledgements: I thank all observers who submitted their data, either through Atlas ptic NOAGS or directly to the author: Tilen Basle, Mateja Berce, Tomaž Berce, Gregor Bernard, Blaž Blažič, Luka Božič, Dejan Bordjan, Jernej Debevec, Benjamin Denac, Damijan Denac, Katarina Denac, Mitja Denac, Gregor Domanjko, Dare Fekonja, Matej Gamser, Robi Gjergjek, Dušan Klenovšek, Urša Koce, Peter Krečič, Miha Krofel, Janez Leskošek, Kristjan Malačič, Gaber Mihelič, Kalina Mihelič, Nace Mihelič, Ruj Mihelič, Tomaž Mihelič, Brigita Mingot, Matija Mlakar Medved, Dijana Mohar, Jure Novak, Rafael Pintar, Mojca Podletnik, Luka Poljanec, Nejc Poljanec, Tomaž Remžgar, Dragana Stanojević, Željko Šalamun, Dare Šere, Anže Škoberne, Iztok Škornik, Tanja Šumrada, Tomi Trilar, Barbara Vidmar, Jani Vidmar, Robert Vilhar, Miha Žnidaršič. Tanja Šumrada's help with preparing the map is gratefully acknowledged.

\section{Povzetek}

Rdečenoga postovka Falco vespertinus je kot gnezdilka razširjena od vzhodne Evrope do severa osrednje Azije. Njena jesenska selitvena pot $\mathrm{v}$ južno Afriko poteka bolj vzhodno kot spomladanska. V Sloveniji se vrsta redno pojavlja na spomladanski selitvi, veliko redkeje pa jeseni. Občasno pride do invazij, ko je vrsta nadpovprečno številna, pojavlja pa se tudi na območjih, kjer je sicer redka. Takšna invazija se je v Sloveniji zgodila spomladi 2015. Podatke o opazovanjih smo pridobili iz spletne podatkovne baze Atlas ptic - NOAGS, s pozivi k zbiranju podatkov na novičarskih skupinah ter neposredno od opazovalcev. Opazovanih je bilo 3910-4370 osebkov te vrste, kar je 3,1-7,2 \% evropske gnezdeče populacije. Višek selitve je bil med 13. in 18. 5., največje število, zabeleženo v enem dnevu, pa 1146. Največ ptic, ki so se prehranjevale in prenočevale, je bilo opaženih na Ljubljanskem barju, predvsem med Škofljico in Igom (567-883 osebkov) ter na Cerkniškem jezeru (710 osebkov). Večje seleče se jate so bile opažene tudi v Št. Juriju pri Grosuplju (500 osebkov), Veliki Pirešici pri Žalcu (406 osebkov) in na Ormoškem jezeru (206 osebkov). Nadpovprečno veliko število rdečenogih postovk so opazili tudi drugje v Evropi, od Iberskega polotoka prek južne Francije, Švice in južne Nemčije do severne Italije in južne Avstrije. Invazije te vrste $\mathrm{v}$ preteklosti so povezovali z večjim številom majskih hroščev Melolontha sp., s katerimi se vrsta hrani, in močnimi vzhodnimi ter jugovzhodnimi vetrovi, ki selitveno pot prestavijo proti zahodu. Noben od omenjenih vzročnih dejavnikov leta 2015 ni bil prepričljivo izražen. Invazija te vrste v Sloveniji je bila prvič podrobno dokumentirana, podatki pa potrjujejo, da sta Cerkniško jezero in Ljubljansko barje najpomembnejši lokaliteti za to vrsto.

\section{References}

ATLAS PTIC (2015): Rumeni vrtnik Hippolais icterina. [http://atlas.ptice.si/atlas], 13/12/2015.

BirdLife International (2015): Species factsheet: Falco vespertinus. - $\quad$ http://www.birdlife.org/datazone/ species/factsheet/22696432], 13/12/2015.

Bordjan D. (2010): Rdečenoga postovka Falco vespertinus. Acrocephalus 31 (145/146): 156.

Bordjan D. (2012): Vodne ptice in ujede Cerkniškega polja (južna Slovenija) v letih 2007 in 2008, s pregledom zanimivejših opazovanj do konca leta 2010. Acrocephalus 33 (152/153): 25-104.

Bordjan D., Božič L. (2009): Pojavljanje vodnih ptic in ujed na območju vodnega zadrževalnika Medvedce (Dravsko polje, SV Slovenija) v obdobju 2002-2008. Acrocephalus 30 (141/142/143): 55-163.

Chevalier F., Qninba A., Bergier P. (2015): Afflux de Bondrées apivores (Pernis apivorus) et autres espèces près de Dakhla, Sahara Atlantique, lors d'un fort épisode de sirocco. - Go-South Bulletin 12: 39-45.

Denac K., Mihelič T., Božič L., Kmecl P., Jančar T., FigeLJ J., Rubinić B. (20I I): Strokovni predlog za revizijo posebnih območij varstva (SPA) z uporabo najnovejših kriterijev za določitev mednarodno pomembnih območij za ptice (IBA). Končno poročilo (dopolnjena verzija). Naročnik: Ministrstvo za okolje in prostor. - DOPPS BirdLife Slovenia, Ljubljana.

Ferguson-Lees J., Christie D. A. (200I): Raptors of the world. - Christopher Helm, London.

Geraldes H. (2015): Large numbers of Red-footed Falcons are unexpectedly seen in Portugal. - [http://www.wilder. $\mathrm{pt} / \mathrm{english} /$ large-numbers-of-red-footed-falcons-areunexpectedly-seen-in-portugal/], 13/12/2015.

Gil Velasco M. (2015): What the hell is going on? - [https:// birdingbytrain.wordpress.com/2015/05/27/what-thehell-is-going-on/], 01/12/2015. 
Glutz von Blotzheim U. N., Bauer K. M., Bezzel E. (1989): Handbuch der Vögel Mitteleuropas. Band 4. AULA Verlag, Wiesbaden.

Glutz von Blotzheim U. N., Bauer K. M. (I99i): Handbuch der Vögel Mitteleuropas. Band 12/I. - AULA Verlag, Wiesbaden.

HAGEMEIJER W. (1994): [Largest-ever invasion of Red-footed Falcons Falco vespertinus in The Netherlands in spring 1992]. - Limosa 67: 7-14. (in Dutch)

Illa M. (2015): Red-footeds galore. - [http://birdingmarc. blogspot.si/2015/06/red-footeds-galore.html], $13 / 12 / 2015$.

Maumary L., Vallotton L., Knaus P. (2007): Die Vögel der Schweiz. - Schweizerische Vogelwarte, Sempach \& Nos Oiseaux, Montmollin.

Kmecl P., Rižner K. (1993): Pregled vodnih ptic in ujed Cerkniškega jezera; spremljanje številčnosti s poudarkom na preletu in prezimovanju. - Acrocephalus 14 (56/57): 4-31.

Matias R., Catry P., Costa H., Elias G., Jara J., Moore C. C., Tomé R. (2007): [Systematic list of the birds of Mainland Portugal]. - Anuário Ornitológico 5: 74-132. (in Portuguese)

MAYer J., Kratzer D. (2009): Einflug des Rotfußfalken Falco vespertinus im Frühjahr 2008 im Baden-Württemberg. Ornithologische Jahreshefte für Baden-Württemberg 25 (2): 129-134.

Nightingale B., Alsopp K. (1994): Invasion of Red-footed Falcon in spring 1992. - British Birds 87 (5): 223-231.

Oliver C. (2015): Red-footed Falcon and Icterine Warbler influx in Catalonia. - [https://elpolitcantaire.wordpress. com $/ 2015 / 05 / 22 /$ red-footed-falcon-icterine-warblerinflux-in-catalonia/], 13/12/2015.

Orbán Z. (2015): „Ubul” returned to the Danube Delta after he had covered a 33.000-kilometre-long journey. [http://falcoproject.eu/en/content/ubul-returneddanube-delta-after-he-had-covered-33000-kilometrelong-journey], 13/12/2015.

Romano H., Correia-Fagundes C., Zino F., Biscoito M. (2010): Birds of the archipelagos of Madeira and the Selvagens II - New records and checklist update (19952010). - Boletim do Museu Municipal do Funchal 60 (326): 5-44.

ScHmid H. (2015): Large-scale invasion of Red-footed Falcons. - [http://files.biolovision.net/www.ornitho. ch/pdffiles/news/redfootedfalconsmall-7681.jpg], $13 / 12 / 2015$.

Tome D., Sovinc A., Trontelj P. (2005): Ptice Ljubljanskega barja. Monografija DOPPS št. 3. - Društvo za opazovanje in proučevanje ptic Slovenije, Ljubljana.

Volet B., Gerber A. (2009): Seltene und Bemerkenswerte Brut- und Gastvögel und andere ornithologische Ereignisse 2008 in der Schweiz. - Ornithologische Beobachter 106 (4): 401-418.

WiND BIRDS (2015): May 2015 - visitant birds to Madeira. [http://www.madeirabirds.com/may-2015-visitantbirds-madeira], 13/12/2015.

Prispelo / Arrived: 15. 12. 2015

Sprejeto / Accepted: 25. 1.2016 